Universidad de Lima

Facultad de Comunicación

Carrera de Comunicación

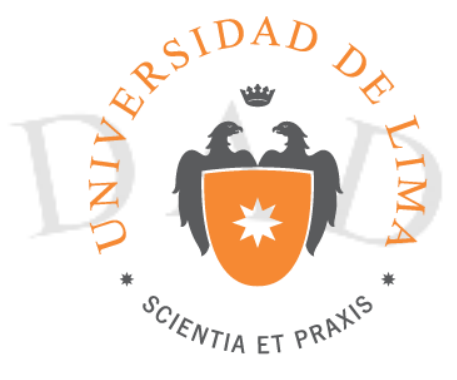

\title{
FRAGILIDAD MASCULINA EN LA FICCIÓN TELEVISIVA PERUANA: EL CASO DE LA REINA DE LAS CARRETILLAS
}

Trabajo de investigación para optar la licenciatura en Comunicación

\section{JAMES ANTHONY DETTLEFF PALLETE \\ Código 19802181}

Asesora

María Teresa Quiroz Velasco

$$
\text { Lima - Perú }
$$

Noviembre de 2015 
Índice

$\begin{array}{lr}\text { 0. Presentación } & 2\end{array}$

1. Marco Teórico 3

$\begin{array}{ll}1.1 \text { Representación Social } & 3\end{array}$

1.2 Género y Masculinidades $\quad 6$

1.3 La ficción televisiva y La reina de las carretillas 11

2. Hipótesis y metodología $\quad 13$

3. Análisis de personajes $\quad 15$

3.1 Pedro 15

$\begin{array}{ll}\text { 3.2 Lázaro } & 17\end{array}$

$\begin{array}{ll}3.3 \text { Kike } & 19\end{array}$

$\begin{array}{ll}3.4 \text { Próspero ("'popó) } & 20\end{array}$

\begin{tabular}{l|l|l}
3.5 & Armando & 21
\end{tabular}

4. Las masculinidades presentes en La reina de las carretillas $\quad 22$

$\begin{array}{lr}\text { 5. Discusión } & 29\end{array}$

6. Referencias 31

$\begin{array}{ll}\text { ANEXO } & 35\end{array}$ 


\title{
Fragilidad masculina en la ficción televisiva peruana: el caso de La Reina de las carretillas
}

\begin{abstract}
El presente artículo es el resultado de la investigación sobre masculinidades representadas en la ficción televisiva peruana. Para ello, se eligió la miniserie peruana La reina de las carretillas (Del Barrio Producciones - América Televisión, 2012). A partir de la construcción de una matriz de análisis y de trabajo cualitativo sobre las formas de representación, se analiza las masculinidades en cinco de los personajes masculinos del relato. La propuesta supone una representación de diversas masculinidades, alejadas de la masculinidad patriarcal, en un relato que está principalmente dominado por personajes femeninos empoderados, proactivos, con agencia, respondiendo a una representación de la crisis de la masculinidad patriarcal. Palabras clave: Género, masculinidad, televisión, ficción, representaciones sociales, Perú
\end{abstract}

\section{Presentación}

La televisión se ha convertido en un articulador de la realidad, promoviendo imaginarios a través de diversos productos televisivos, mostrando modelos que son consumidos por los televidentes y logrando influencia en la formación de comportamientos sociales. Así, la televisión muestra patrones culturales que definen a una sociedad.

En el caso de la ficción, se reproducen imaginarios a partir de los roles y comportamientos que sus personajes performan. Con respecto al género -entendido como construcción cultural a partir de la diferencia sexual-, los roles de lo masculino, lo femenino y otros géneros que salen de la visión binaria, responden a los mandatos que la sociedad construye sobre cada uno de ellos.

En el caso específico de la ficción, la televisión construye y reproduce imaginarios de una sociedad a partir de los roles y comportamientos que sus personajes performan. Con respecto al género -entendido como construcción cultural a partir de la diferencia sexual-, se representan los roles de lo masculino, lo femenino y otros géneros que salen de la visión binaria, respondiendo a los mandatos que la sociedad construye sobre cada 
uno de ellos. De esta manera los productos televisivos generan sentido en cuanto a los roles de género, mostrando a través de ellos formas de comportamiento que representan una manera de plantear la sociedad en que son producidos.

Consideramos que la ficción melodramática tiene una tradición de representaciones de género principalmente heteronormativa, que refuerza los valores tradicionales de la sociedad patriarcal. Sin embargo, en las últimas décadas se ha podido observar que ese modelo tradicional ha empezado a mostrar cambios en las ficciones y en los personajes que propone, lo que a la vez puede estar reflejando los propios cambios que se han ido dando en la sociedad y con ello estas ficciones podrían estar proponiendo cambios en los comportamiento de los sujetos masculinos. Estos cambios son performados -no sin fricciones y resistencias- en las diversas sociedades actuales. Y desde la representación, las ficciones televisivas muestran a los sujetos en este tránsito de la masculinidad.

Por este motivo nos interesa analizar las representaciones masculinas en la ficción televisiva. Para ello nos concentraremos en la miniserie peruana La Reina de las carretillas, y específicamente en sus personajes masculinos. Esta miniserie muestra mujeres emprendedoras, que salen adelante solas, sin necesariamente el apoyo o guía de una pareja masculina, como sí se daba en los relatos tradicionales. Por ello resulta interesante ver el rol que se propone para los personajes masculinos en una ficción que presenta a personajes femeninos tan empoderados.

\section{Marco Teórico}

\subsection{Representación social}

Para el trabajo que planteamos aquí, nos interesa el concepto de la representación, pues este engloba la idea que nuestra relación con el mundo no es una relación objetiva. Abric plantea que "no existe realidad objetiva. Toda realidad es representada, apropiada por el individuo o el grupo, y reconstruido en su sistema cognitivo" (Abric, 2011, p. 12). Aceptando que no existe una realidad objetiva, externa como tal, fuera de una interpretación social, comprendemos que nuestro entendimiento del mundo y de aquello que sucede en él está intermediado por los esquemas de la propia sociedad y por la ideología, que como bien nos recuerda Hall es un sistema de representación materializado en prácticas sociales (Hall, 2010, p. 207). De esta manera, las prácticas sociales visibilizan el sistema de normas existentes en una sociedad, las 
concretizan, y conforman las representaciones y la forma en que comprendemos el mundo y nos relacionamos con él a partir del tamiz de la ideología. Y a partir de ello los comportamientos de los individuos estarán definidos por este tamiz.

Así, para interactuar en la sociedad necesitamos de patrones, normas que rijan las formas de comportamiento, que permitan a la sociedad funcionar y desarrollarse con la participación de todos sus individuos. Para ello, se maneja un conjunto de modelos que permiten interpretar los significados sociales, a los cuales conocemos como representación social. Abric nos propone que la representación es una "visión funcional del mundo que permite al individuo o al grupo conferir sentido a sus conductas y entender la realidad mediante su propio sistema de referencias" (Abric,2011, p. 13).

Es decir, a partir de las representaciones sociales es que dotamos de sentido a los diferentes elementos de la realidad, haciendo que exista un sistema de referencias que permita un comportamiento "adecuado", y legitime (cargue de sentido) nuestras propias acciones.

Sin embargo el sistema de referencias no es único, y las maneras de representación tampoco. Hall propone que "lo importante de los sistemas de representación es que no son singulares" (Hall, 2010, p. 208), es decir, no hay un solo sistema, y de esta manera los individuos pueden tener diferentes comportamientos a partir de situaciones y grupos sociales distintos en los que puedan verse envueltos.

En su exposición sobre las funciones de las representaciones sociales, Abric plantea que entre otras, está la identitaria, que permite definir la identidad y salvaguarda la especificidad de los grupos, lo que se relaciona con el control social ejercido por la colectividad sobre cada uno de sus miembros (Abric, 2011, p. 15-17). Esto nos plantea que al actuar sobre el comportamiento de los individuos, al proveerlos de una referencia de la manera de interactuar socialmente, está también a la vez salvaguardando las formas en que esta sociedad actúa y está estructurada, aquello que considera comportamientos adecuados.

El medio televisivo es un aparato que se presenta constantemente como reproductor de la realidad, aunque varios autores han demostrado ya que lo que muestra es más una representación de esa realidad, y Bordieu (1997) explicita que se ha transformado de un instrumento de registro, en un dispositivo para crear la realidad. 
De cualquier manera, en muchos casos los individuos nos relacionamos con el mundo a través de la intermediación televisiva; mientras más lejanos los lugares mayor intermediación existirá de los diferentes medios -entre ellos, la televisión-, pues existirán menos posibilidades de una relación directa con esa realidad. De esta forma, los sujetos manejamos el conocimiento y adoptamos posiciones sobre lo que sucede en la realidad a través de la representación que de ella hacen los medios, como la televisión. Si bien se podría pensar que esto sucede principalmente con los programas que se entienden son programas "de realidad", como los informativos, también se da en buena medida con los programas de ficción, a pesar que el público pueda entender que aquello que ve no es real, pues lo recoge como una representación de esa realidad, una puesta en escena basada en algo que es real. Fuenzalida propone que la gente observa los relatos de ficción y espera que en ellos esté presente "la vida", algo que puedan reconocer como suyo, y nos indica que "la gente se apropia de aquello en lo que se reconoce" (Fuenzalida 1996, p. 102).

La ficción televisiva propone a su público representaciones de comportamiento, modelos, relaciones y normas que responden a la sociedad en la que se producen los mensajes televisivos. Estos mensajes desarrollan discursos que por lo general responden a la ideología hegemónica, y reflejan los valores y costumbres de esa sociedad. En el caso de América Latina, el melodrama es uno de los tipos de ficción que mayor calado tiene en la población, y en sus relatos se proponen modelos de comportamiento y de género, por lo que observarlos resulta interesante ya que en los múltiples círculos de la formación del género (el hogar, la escuela, la iglesia, etc.), no podemos dejar de lado aquel que proviene de los medios de comunicación.

El papel que mujeres y hombres cumplen -o deben cumplir- en la sociedad, está propuesto en muchos de los relatos del melodrama latinoamericano, y éste ha ido variando a partir de los propios avances de las sociedades y de la comprensión de los valores que cada uno posee en ellas. Por ejemplo, en producciones más clásicas, el rol representado y propuesto para las mujeres responde a aquel que la ubica como madre de familia, servicial, al cuidado de la casa y bajo la protección/dominio del varón. Producciones más contemporáneas no han abandonado del todo esa representación, pero sí han dado espacio para representaciones diferentes, para propuestas de personajes femeninos menos dependientes de la figura masculina. Algunas hipótesis feministas dejan de lado la visión del melodrama como instrumento subyugador de la mujer e 
indican que "la telenovela legitima y valora socialmente un discurso femenino que ha sido tradicionalmente desvalorizado y considerado irrelevante por la sociedad patriarcal”. (Fuenzalida, 1996, p. 93) De esta forma podemos considerar que la telenovela (y sus relatos melodramáticos) empoderan a la mujer y sus discursos, y potencialmente pueden entrar en conflicto con el discurso masculino. Frente a una sociedad en que el discurso patriarcal pierde fuerza, la representación de las mujeres toma otra perspectiva, al igual que la de los hombres.

\subsection{Género y masculinidades}

Para avanzar en este trabajo debemos definir qué entendemos por masculinidad, lo cual nos lleva a explicitar cómo definimos el género. Entendemos género como la construcción que se hace de los individuos de la sociedad, a partir de diferencias sexuales, que genera significados que se plantean en prácticas y discursos que definen sus conductas. En ese sentido, trabajamos bajo la propuesta de Lamas, quien propone que "el género es un sistema de relaciones culturales entre los sexos (...) una construcción simbólica, establecida sobre los datos biológicos de la diferencia sexual" (Lamas, 1996, p. 12), “es una especie de 'filtro' cultural con el que interpretamos el mundo y a nosotros mismos, y también una especie de armadura con la que constreñimos nuestra vida”. (Lamas, 1995, p. 62)

Al ser una construcción social, va a estar determinado por la época, el lugar y la sociedad en que es generado, por lo que puede variar en épocas y lugares diferentes, aunque sus cambios tienden a darse de manera muy lenta.

Estas construcciones van a establecer discursos normativos sobre lo que es y cómo deben ser los sujetos generizados. Para ello se trabajan y manejan representaciones de género en diversos medios, y diversas instituciones socializan esas representaciones y las refuerzan a través de los discursos de los roles de género, y de las relaciones en las cuales son reproducidas. Este discurso se va adaptando también a medida que los individuos van creciendo, pues la construcción se va a dar gradualmente y tiene mandatos específicos para cada etapa del crecimiento de las personas.

Las construcciones y representaciones de género, como parte de la ideología dominante de la sociedad, preconfigura una serie de acciones, actividades, esperanzas y expectativas para los hombres y las mujeres en la sociedad. De esta forma, Hall advierte 
que "en realidad somos hablados y se habla por nosotros" (en los discursos ideológicos). "El niño recién nacido (...) es ya esperado, nombrado y posicionado de antemano por las formas de la ideología." (Hall, 2010, p. 214).

El sistema heteronormativo ejerce una gran presión para el caso de la identidad masculina, la cual es constantemente vigilada, exigiendo que se demuestre continuamente, y esperando una serie de acciones y actitudes que reafirmen su poder.

Estas acciones están destinadas a lograr las características de una masculinidad que es a la que se debe aspirar, una serie de comportamientos que permitirán a un sujeto sentirse hombre completo. Este ideal que predomina en la sociedad es lo que se denomina masculinidad hegemónica, que en palabras de Kimmel es "la imagen de masculinidad de aquellos hombres que controlan el poder, que ha llegado a ser la norma, destinada a enseñar a los hombres jóvenes cómo llegar a ser 'verdaderos hombres"' (Kimmel, 1997, p. 51)

Como afirma Brandes, las identidades masculinas se desarrollan en relación a la mujer (Brandes, 1980, citado por Cruz y Ortega, 2007, p. 128), y principalmente esa es una relación de poder donde el hombre se siente superior a la mujer y ejerce su dominio sobre ella, pero a la vez se carga de responsabilidades que terminarán por definirlo como un sujeto masculino valioso o no.

De esta forma, lo que existe en esta relación entre hombres y mujeres es una asimetría, que se produce y reproduce en el intercambio de los bienes simbólicos (ritos, mitos, relaciones de parentesco, matrimonio) y materiales (Bordieu 2000, p. 59-61). Para el sistema patriarcal, el hombre se constituye como el ser responsable de proveer a la familia los elementos que le permitan el éxito, la subsistencia, el avance, y el prestigio. Es el hombre el responsable del honor de la familia, de la continuación del linaje, y en general de la imagen de la familia. El padre de familia será quien trabaje, quien imponga el orden, quien tome las decisiones principales y determine la distribución de los recursos y afectos.

Un hombre que no logre mantener a su familia, que no sepa defender su honor, que la lleve por el camino del decaimiento antes que el éxito, será un sujeto debilitado, desvalorado, despreciado. La figura del padre proveedor, del patriarca, del páter familia, es la figura suprema en el sistema patriarcal heteronormativo, y es más un ideal que una 
realidad. Sin embargo se espera que los hombres aspiren a ese nivel, y que se esfuercen en lograr la gran mayoría de sus cualidades.

Frente a este ideal patriarcal, coexisten otras realidades y masculinidades, de las cuales explicaremos las más relevantes para nuestro trabajo.

En América Latina la figura del hombre se ha relacionado mucho con el "macho", el hombre que ejerce su poder de manera pública y hace alarde de ello. La reafirmación del macho es constante, y se ejerce tanto en el ámbito privado como el público, ya que es necesario ejercer su dominio no solo ante los pares de la sociedad, sino también frente a su familia, y especialmente sobre su pareja, a quien domina y trata en muchas ocasiones como un objeto de su posesión. Fuller nos indica que en Latinoamérica la masculinidad se relaciona con el machismo, que es "la obsesión del varón por el predominio y la virilidad que se manifiestan en la conquista sexual de la mujer. (...) Dominio sobre las mujeres pero sin asumir su rol de jefe de familia y padre proveedor.” (Fuller, 1997, p. 37) De esta forma, el hombre machista no solo asume su superioridad frente a la mujer, sino que además la explicita, la convierte un hábito, la ejerce incluso con violencia, y si bien está lejos del ideal del modelo de varón patriarcal, se siente poderoso y cumpliendo un rol en la sociedad que le resulta natural, casi como un derecho divino. Justamente, la falta de recursos y la dependencia frente a grupos dominantes configura relaciones de género con exacerbación de dominio masculino sobre las mujeres, ya que es una de las pocas fuentes de prestigio que les queda (Fuller, 2001, p. 40).

Estos modelos de masculinidad se han instalado en las diferentes sociedades desde épocas remotas, y han ido sufriendo pocos cambios a lo largo del tiempo. Se basan en la idea de la superioridad masculina, en su labor de proveedor y protector de la familia, en la posesión de derechos y privilegios que su posición les asegura en la sociedad. Pero tal como lo asegura Hearn, "en las sociedades posmodernas se da el fin de la certidumbre masculina de tener un lugar asegurado en el mundo" (Hearn, 1999, citado por Cruz y Ortega, 2007, p. 122). Los cambios que se han dado en las sociedades actuales han ido modificando la imagen del hombre, sobre todo a partir de las nuevas funciones y posibilidades de acción en el espacio público que han asumido las mujeres. El hecho que la mujer actúe sobre el espacio público -lugar tradicionalmente reservado para los hombres, mientras la mujer actuaba en el espacio privado, el hogar- ha ido 
minando el accionar de los hombres, poniendo en duda su posición privilegiada, y planteando relaciones diferentes entre los diversos géneros. Castells (1998) plantea que los avances en los derechos de la mujer han llevado al fraccionamiento del estado patriarcal, restando poder a los hombres y generando cambios en los sujetos masculinos. Por ello se habla de masculinidades en crisis o de masculinidades cambiantes que asumen nuevas posiciones dentro de la sociedad, y poseen una relación con la mujer que ya no es la de poder absoluto sobre ellas.

Entre esas representaciones de género que se pueden apreciar en la actualidad, está la del hombre igualitario, también llamada por algunos hombre democrático, en la que la posición del varón no es de ejercicio de poder sobre la mujer. El hombre igualitario entiende que los derechos son compartidos, que no existen privilegios y que igualmente las responsabilidades y deberes son comunes al hombre y la mujer. Se comparte tanto el espacio público como el privado, y se establece una relación horizontal, antes que una relación vertical en que uno domina al otro. Pero este tipo de varón, al igual que el patriarcal, es un ideal antes que una realidad. Las raíces de la masculinidad hegemónica son aún fuertes, y subyacen muchas de sus actitudes y costumbres. Sin embargo muchos hombres se proyectan hacia la idea del varón igualitario, comparten labores caseras, comparten la responsabilidad de la crianza de los hijos y del sustento del hogar, sin sentir que eso les resta masculinidad ni los convierte en sujetos de menor valía. Por el contrario, en las sociedades actuales el discurso principal es que ese es el modelo a seguir, respetando a la mujer, respetando y facilitando ${ }^{1}$ sus derechos. Para el caso peruano, Fuller nos indica que en los 90 se ve ya un cambio de sensación y de representaciones de género, aunque esto está más en la racionalización que en la verdadera actitud. (Fuller, 1997, p. 46). De esta forma, si bien el discurso oficial y la actitud general pueden encaminarse hacia una relación más igualitaria-democrática en la relación de los diferentes géneros, la realidad no necesariamente está al nivel de esos deseos. No es poco frecuente que se conozca de casos en que se ha dado una actitud o haya sucedido un hecho que va en contra de estos discursos igualitarios, que además ha sido generado por algún personaje público que constantemente aboga por la relación igualitaria. En un estudio en tres ciudades del país, Fuller concluye que los matrimonios se definen como igualitarios, pero que el hombre mantendrá la posición de autoridad. "Es decir, en el discurso predomina la pareja igualitaria, pero en la práctica se mantiene el modelo asimétrico" (Fuller, 2001,

\footnotetext{
${ }_{1}^{1}$ Esta misma manera de definirlo demuestra cómo subyace el modelo de masculinidad hegemónica, ya que si el varón debe "facilitar" los derechos de la mujer, es porque es quien aún posee el poder sobre las mujeres
} 
p. 472). Pero de todas maneras y a pesar de las contradicciones de la realidad, existe en la sociedad actual un varón que intenta avanzar hacia esa igualdad, y su figura es parte de las representaciones que varias sociedades manejan actualmente.

Finalmente, deseamos hablar de un tipo de masculinidad diferente, que se concretiza en el hombre emasculado. Este tipo de masculinidad está presente en el imaginario social desde épocas remotas, y es a lo que se combate en el modelo de masculinidad hegemónica, ya que en este caso el poder ha sido invertido y el varón es dominado por la mujer. Es un tipo de varón que no ejercerá dominio ni poder sobre la mujer, porque no siente que lo tiene, y por el contrario será ella quien ejerza ese poder. El varón que deje las decisiones a la mujer, que no intente ejercer poder sobre ella podrá ser apreciado por sus pares como un sujeto disminuido, sin valor. "La noción contraria (a la virilidad) es expresada por el adjetivo manso, que significa domesticado y también castrado". (Fuller, 1997, p. 33). A partir de este concepto podemos entender que ser domesticado es perder la libertad del varón, es no tener el privilegio de hacer lo que se desea sin rendir cuentas, y en lo figurativo este sujeto ha perdido lo que lo determina como ser viril -es decir, lo que lo identifica como macho- y se le considera como un ser castrado. Para el macho un hombre emasculado es despreciado, pues ha perdido toda posibilidad de poder, y más aún, le ha otorgado ese poder a la mujer, y por ello la masculinidad hegemónica reclamará constantemente esta "traición". Los pares remarcarán esta situación de poder perdido adjetivizando constantemente la situación de desventaja frente a la mujer que ha asumido el sujeto emasculado. Pisado (por la mujer), sacolargo, títere (de la mujer) son algunos de los términos que se utilizan comúnmente para referirse a este tipo de masculinidad, remarcando la situación de inferioridad del varón. Y en la verbalización más clara de las representaciones de masculinidad perdida, están la de afirmar que no tiene pantalones (o no los lleva puestos) o no tener huevos, lo que se relaciona directamente con la castración, con la pérdida de virilidad característica del macho.

No debemos sin embargo confundir al hombre emasculado con el hombre igualitario, pues este último comparte el poder con su pareja, la negocia, pero conserva para sí una buena parte de ella. En un estudio sobre el comportamiento de hombres de la clase media limeña, Fuller observó que las nuevas generaciones son más democráticas, y "representan a las mujeres como compartiendo la toma de decisiones, pero nunca como las que las lideran." (Fuller 1997, p. 160). Vemos cómo la idea del 
hombre igualitario es entonces un tránsito, un ideal, un intento por cambiar una situación de desigualdad con sus parejas que racionalmente entienden como injusta.

Es posible que el hombre igualitario pueda ser también menospreciado por los varones-machos, ya que comparte actitudes y labores que son identificadas como femeninas, pero su parte de poder aún le permite legitimarse ante sus pares, estando además protegido por el respeto a la mujer y sobre todo por los discursos más igualitarios de la sociedad actual.

Debemos finalmente indicar que la masculinidad relacionada al machismo no es necesariamente aceptada por la masculinidad hegemónica, pues carece de algunos elementos que son centrales para acercarse al ideal del modelo patriarcal. La responsabilidad, la producción, y la paternidad son elementos centrales para lograr el nivel adecuado de hombre maduro, el paso de un macho a verdadero hombre. Ya Fuller advierte que la virilidad debe ser acompañada por la responsabilidad, "de otro modo un hombre es tan solo reproductor, y no un varón logrado." (Fuller 1997, p. 169). De esta manera, hombres viriles, padres irresponsables, hombres que no se vuelven proveedores y organizadores del núcleo familiar, estarán en un estadio que aún no les permite acercarse a la imagen del varón completo.

\subsection{La ficción televisiva y La reina de las carretillas}

La eficiencia de la TV es más bien motivadora en el ámbito de afectos y actitudes. Puede muy bien difundir masivamente, otorgar visibilidad, legitimar, prestigiar y valorar. (Fuenzalida, 1996, p. 102)

Varias ficciones peruanas de la última década muestran a hombres y mujeres distintos a aquellos representados en décadas anteriores. Si bien el melodrama latinoamericano clásico tiene a una mujer como protagonista de la historia, tradicionalmente esta mujer era un sujeto fragilizado, víctima, sumiso, que necesitaba de la presencia de un sujeto masculino, -comúnmente un hombre con algún tipo de poder, proveedor, proactivo-, que permitiría la realización del personaje femenino. Las ficciones contemporáneas muestran cada vez más personajes femeninos diferentes, mujeres proactivas, emprendedoras, que surgen sin la necesidad de una pareja 
masculina, y resuelven sus problemas de manera independiente. A la vez, los sujetos masculinos empiezan a mostrarse de manera distinta, con un rol que ya no los ubica en el espacio clásico, y que en algunas oportunidades los muestra fragilizados y subalternos. Si bien en muchas ficciones contemporáneas se puede presentar una pugna de poderes entre los géneros representados, a medida que ha ido avanzando una representación más igualitaria, se han generado relatos donde la pugna se da entre mujeres, y ya no entre mujeres y hombres. Este es el caso de La Reina de las carretillas, donde el relato presenta la historia de mujeres con diferentes niveles de poder, que se enfrentarán entre sí para lograr sus objetivos.

Esta miniserie fue producida en el año 2012 por Del Barrio Producciones, y emitida por América Televisión logrando alta sintonía, ubicándose como la tercera ficción más vista del año, con un promedio de share de 43.37\% (Obitel 2013, p. 409). Cuenta la historia de Estrella, una humilde mujer con gran habilidad para la cocina, que vive en Lobitos -un pueblo de pescadores en el norte del Perú- con Lázaro, su esposo y padre de su futura hija. Los maltratos de Lázaro la hacen huir a la capital, Lima, donde empieza una nueva vida vendiendo comida en un mercado. Apoyada por la dueña del mercado (Doralisa) y una amiga (Lily) va surgiendo gracias a su esfuerzo, trabajo, y la comida que prepara. Para ello deberá enfrentarse a Inés, su amiga de infancia que inicialmente parece apoyarla, pero es la antagonista del relato. Estrella conoce en Lima a Pedro, quien también trabaja en el mercado arreglando aparatos eléctricos, y el romance surge entre ellos. Inés envidia a Estrella y lo que ella representa (maternidad, dotes para la cocina, afecto, simpatía) y tratará de quedarse con todo lo que Estrella logre, incluida su hija. Luego de varios giros argumentales y problemas para la protagonista, Estrella logrará triunfar en su negocio de comida, y se casará con Pedro.

Además de Pedro y Lázaro, existen otros personajes masculinos importantes en el relato. Próspero es el esposo de Doralisa, y administra el mercado y los negocios de ambos. Kike es esposo de Lily al inicio del relato, pero su infidelidad con Inés hará que sea expulsado del hogar. Los hijos de Doralisa y Próspero son Rommel y Aníbal, jóvenes que están en edad universitaria, y buscan ubicarse en el esquema social de maneras diferentes: Aníbal a través de la música y Rommel a través de los estudios, pero también a través de sus dotes de repostero. Armando es un veterinario, hermano de la pareja de Aníbal, que en un primer momento tendrá un romance con la hermana de Doralisa, pero finalmente será la nueva pareja de Lily. Junto con estos personajes aparecen además el Teniente Ocampo (la autoridad institucional frente a ciertos 
crímenes que se darán en el relato); Jonás, alias Pantera (instrumento para cometer las fechorías y atentados urdidos por Inés); José (hermano de Pedro que cometió un delito de joven, por el cual Pedro se inculpó), etc. Pero la repercusión de estos personajes en el relato central es bastante menor.

Para este trabajo nos concentraremos en cinco de los personajes principales, que muestran ya edad suficiente para plantear una masculinidad definida: Pedro, Lázaro, Kike. Próspero y Armando.

\section{Hipótesis y metodología}

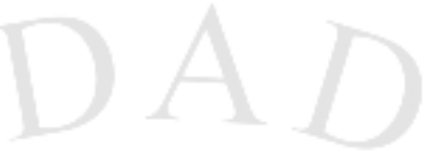

Partimos de la idea que en ciertos relatos de ficción modernos se evidencia la crisis del sistema patriarcal, y en esa línea la representación de los personajes masculinos muestran variaciones con respecto a la masculinidad patriarcal. Estas variaciones pueden observarse en una ficción melodramática como La Reina de las carretillas.

De esta manera se planteamos lo siguiente

\section{- Hipótesis:}

Los personajes masculinos en la miniserie peruana La Reina de las carretillas son formas de representación distintas de la masculinidad patriarcal.

Esta hipótesis, nos lleva a las siguientes preguntas de investigación

-¿Qué tipos de masculinidades presenta la miniserie peruana La reina de las carretillas?

-¿Cómo se relacionan estas masculinidades con la masculinidad patriarcal?

Para lograr contestar estas preguntas, se utilizó un método de trabajo cualitativo, centrado en el análisis de los personajes. A través de la revisión de la totalidad de los capítulos emitidos de la serie, realizamos un trabajo de análisis de la manera en que los personajes masculinos son representados, utilizando para ello una matriz de análisis que permitiera observar las formas de representación de los personajes, su caracterización y sus elementos de masculinidad. Esta matriz de análisis se realizó tomando en consideración las propuestas de creación de personajes desarrolladas por Syd Field, la ficha de análisis propuesta por Mily Buonnano en el trabajo del observatorio GEMMA y la ficha de análisis propuesta por Elena Galán. De esta forma, nuestra matriz considera las siguientes dimensiones: 
-Dimensión física, con las categorías de cuerpo, rostro, vestuario, accesorios utilizados, edad y etnia. Estos aspectos nos indican las características visibles del personaje, su caracterización a partir de aspectos que se presentan como "naturales" (cuerpo -a pesar que este también se construye y configura genéricamente- edad, etnia) y elementos culturales (vestuario, accesorios).

-Dimensión psicológica, con las categorías de pasado del personaje, personalidad/temperamento y objetivos. Estos nos configuran un ámbito psicológico del personaje, que propone metas para sus acciones, refleja la manera en que lleva adelante ese accionar, y lo relaciona a la formación que ha tenido socialmente en su vida.

-Dimensión social, con las categorías mundo profesional, mundo privado, uso de tiempo de ocio, clase social y estado civil. Estos aspectos nos proporcionan dos dimensiones del personaje, ya que por un lado nos ofrecen entender el grado de inserción del personaje al mundo laboral -que lo ubica en el plano del varón proveedory el desarrollo de su masculinidad en el ámbito público; y por otro su accionar independiente, sus momentos en solitario, y el uso de su tiempo fuera de sus obligaciones laborales.

-Dimensión sentimental, con las categorías de relaciones sentimentales, relación familiar, relación con otros varones y relaciones con infantes. Esta dimensión nos ubica en el plano sentimental y más específicamente en las relaciones de género. Provee información sobre relaciones entre los géneros que pueden ser de dominación, apoyo, enfrentamiento o sojuzgamiento. Del mismo modo, ofrece características de relaciones con los pares, que permitirá reafirmar o poner en duda la masculinidad del personaje. Finalmente, la relación con personajes menores de edad permite analizar el plano sentimental que lleva a la manera en que el varón se relacionará con la figura de padre, en sus distintas posibilidades.

Cada uno de los personajes ha sido analizado con la matriz propuesta, viendo las características más saltantes y recurrentes en los casos que variaran de capítulo a capítulo. Si bien en algunos casos ciertas categorías no lograron desarrollarse adecuadamente por la propuesta narrativa(por ejemplo el pasado de los personajes, solo evidenciado en un caso, inferido en otros dos, e imposible de conocer en los dos restantes), la matriz resultó útil para evidenciar las diferencias y similitudes de cada uno de los personajes masculinos. 


\section{Análisis de los personajes}

A través de la matriz de análisis se pueden observar las siguientes características físicas de los personajes trabajados en esta investigación.

\subsection{Pedro}

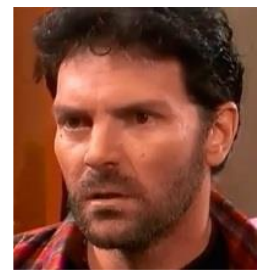

-Es un hombre en el rango de edad de 30 a 35 años, fornido, por lo general arreglado, con lo que podría llamarse "buena presencia". Tiene una barba a medio crecer, pero muy cuidada constantemente, lo que lo aleja de la impresión de simplemente no haberse afeitado. Su vestuario es sencillo, con jeans y zapatos cómodos, y utiliza camisas de cuadros que siempre usa abiertas, dejando ver una camiseta, muchas veces sin mangas (conocida en el Perú como "bividí") -relacionada más a una camiseta deportiva antes que a ropa interior- que permiten ver la forma de sus pectorales. Pedro utiliza una gargantilla de cuero delgada, y es un personaje que para el imaginario peruano se diría que es "blanco"2.

En la dimensión psicológica se representa a Pedro como un ser sensible, calmado en su comportamiento cotidiano, pero que puede exaltarse cuando se enfrenta a un acto de injusticia. De los cinco personajes analizados es del único que se plantea con claridad un pasado, ya que se descubre que ha estado en la cárcel acusado de asalto, pero que salió de ella luego de cumplir su condena y tener buena conducta. En la cárcel es que aprende el oficio de arreglar aparatos eléctricos, y eso le ha permitido subsistir desde que salió de prisión. Pedro desea salir adelante sin que nadie lo juzgue por su pasado, y tras la llegada de Estrella su objetivo es conquistarla, y mientras lo hace, se convierte en su defensor, sobre todo por las injusticias que se cometen con ella.

En la dimensión social, Pedro aparece durante todo el relato como un hombre soltero, sin compromiso, excepto el que finalmente establece con Estrella. Otros personajes femeninos intentan conquistarlo desde el inicio del relato, pero su interés por Estrella hará que nunca haya siquiera un atisbo de relación con otra mujer. Pedro se presenta (como gran parte de los personajes) como parte de una clase socioeconómica de recursos económicos reducidos, que se gana la vida con su trabajo de reparar equipos eléctricos en un puesto del mercado. Sin embargo, en una incongruencia del relato, en algunos momentos cuando Estrella necesita dinero, Pedro la apoyará económicamente.

\footnotetext{
${ }^{2}$ El actor que lo interpreta es hijo de un renombrado director de cine peruano, y una conocida guionista, provenientes de familias acomodadas.
} 
Aún así, no se sentirá que Pedro sea una persona con muchos recursos económicos, y su trabajo será solo el que ya se ha explicado. No se ve mucho a este personaje en sus momentos de ocio, más allá de aquellos en que comparte esos momentos con los demás miembros del relato (alguna fiesta o celebración del mercado donde trabajan), que serán los momentos que aprovechará para acercarse a Estrella y estar con ella. Más allá de esos momentos, parece siempre estar trabajando, o en camino a recoger/dejar algunos equipos de su trabajo. Pero hay algo que lo destaca de los demás personajes masculinos: es de los pocos que se muestra solitario en algunos momentos. En estas ocasiones Pedro muestra su lado sensible, recuerda a su hermano, recuerda momentos tristes de su pasado y llora, o por el contrario, recuerda los momentos que está construyendo con Estrella. Sus momentos de soledad se relacionan de esta manera a su lado más sensible.

En la dimensión sentimental, más allá de lo ya indicado en el párrafo anterior, se sabe que tiene un hermano menor, el cual estuvo involucrado en un asalto, pero Pedro llegó y lo hizo huir, inculpándose del delito y purgando condena. No se conoce nada del resto de la familia del personaje (padres, otros parientes). Esta actitud de responsabilidad por el hermano y el autosacrificio le confieren una dimensión heroica al principal personaje masculino del relato. Esa dimensión de personaje adulto protector se desarrolla también con Yazmín, única niña en el relato, que vende comida de manera ambulante para ayudar a solventar los gastos de su casa, donde vive con su abuelo enfermo. Pedro está siempre preocupado por Yazmín, vigilando que no deje los estudios, que no se quede hasta tarde, que no ande por lugares inseguros. Pedro se constituye de esta manera en un personaje que cuida a los más desvalidos, y aunque a veces corto de recursos, tratará de defenderlos siempre aún con su propio sacrificio. En cuanto a las relaciones sentimentales, como ya adelantamos en un párrafo previo, su única relación es con Estrella, a pesar de los avances de otros personajes femeninos. Su relación con ella será siempre de apoyo, de consejo, pero nunca de indicarle o imponerle idea alguna. En lo que respecta a su relación con los otros personajes masculinos, hay variedad dependiendo de quien se trate. La relación con Kike es variable, y demuestra una incongruencia en el relato. En los primeros capítulos parecen personajes enfrentados, que no confían en el otro e incluso desprecian las acciones del otro. Hay un par de escenas en que Pedro se burla de Kike a partir de sus infortunios y errores. Sin embargo, luego del capítulo 6 su relación se torna más amical, e incluso de complicidad (cuando Pedro se entera de la infidelidad de Kike), lo cual se mantendrá 
hasta el final del relato. Por el contrario la relación de Pedro con Lázaro será de constante enfrentamiento, al ser antagonistas en la lucha por el amor de Estrella. En los enfrentamientos físicos Pedro saldrá vencedor, no solamente contra Lázaro sino también al enfrentar a otros hombres físicamente, con la excepción de una escena, en que varios delincuentes logan reducirlo y golpearlo. En general, los demás personajes dirán que Pedro "sabe pelear como nadie" (conocimiento que adquirió en la cárcel) y eso reafirmará su hombría y virilidad ante los demás.

\subsection{Lázaro}

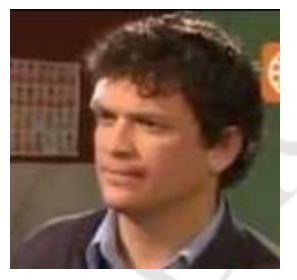

-El rango de edad parece ser similar al de Pedro (entre 30 y 35 años) y si bien al inicio del relato se viste de manera característica a la de los pescadores (pantalón remangado, camiseta) una vez que llega a Lima su vestimenta será con camisa, pantalón y una casaca, vestimenta relacionada a la de un trabajador dependiente. Frecuentemente bien peinado y afeitado, no muestra en el rostro ni en otro lugar del cuerpo accesorios o marcas características. La contextura de Lázaro podría definirse como "promedio". No es un personaje fornido, pero tampoco se muestra débil en su físico. En el primer capítulo se muestra una incongruencia del relato, pues regresando a tierra firme en la lancha en la que trabaja desnuda su torso, mostrando ser una persona que no ha recibido sol en mucho tiempo (lo que en Perú se conoce como "crudo"), algo poco creíble para un pescador de la zona norte del país. Étnicamente se le puede ubicar como un criollo costeño peruano, a quien los peruanos llamarían un "blancón" por un color de piel más claro que el promedio nacional.

En la dimensión psicológica Lázaro es un sujeto cuyo pasado se desconoce. Se puede inferir que viviendo en una caleta de pescadores, sus antepasados eran pescadores y él lo ha sido desde que ingresó al mundo laboral. Es un personaje violento, rencoroso, disconforme con su vida y abusivo con los débiles. Sin embargo frente a otros personajes con mayor poder puede resultar cobarde. Es un ser irresponsable, pues prefiere salir a divertirse solo en vez de pasar tiempo con su esposa embarazada, e incluso llega a robarle dinero para poder salir a beber licor. Luego que Estrella lo abandone (después de una golpiza que él le propina cuando ella descubre que él ha sido infiel), su objetivo será recuperarla, que ella lo perdone, y regrese al hogar con la hija de ambos. 
La dimensión social de Lázaro nos indica que está casado con Estrella, pero eso no le impide serle infiel en varias ocasiones (a lo largo del relato, pero también hay referencias de infidelidades previas). Su oficio es el de pescador, que ni siquiera logra pescar lo mínimo para mantener a su familia. Esto lo ubica en una clase socioeconómica de recursos muy reducidos.

Llegado a Lima no tiene oficio conocido. Simplemente está en la ciudad durante 30 capítulos, sin explicación de cómo subsiste. No se le muestra en un mundo privado, interior, solitario, pero sí en varias oportunidades en sus momentos de ocio: en fiestas, con otras mujeres o dedicado a la bebida.

En la dimensión sentimental Lázaro inicia el relato como un hombre casado con Estrella. Separado de ella, viaja a Lima luego de un tiempo intentando recuperarla. Buena parte del relato será un hombre separado, con una esposa que le exige el divorcio. Mientras tanto, establece una relación con Inés, que por su parte parece ser más una cuestión sexual antes que sentimental. La infidelidad de Lázaro se ve desde el primer capítulo, y más adelante en el relato se descubre que cuando Inés vivía en Lobitos, fueron también amantes. La relación más estable de Lázaro que se conoce durante el relato es justamente con Inés, que lo quiere para sí y finalmente termina embarazada de él. Sin embargo esta será una relación altamente conflictiva, porque Inés es un personaje poderoso, de fuerte carácter, y no permitirá que Lázaro la deje ni tome las decisiones sobre sus vidas y planes. Hacia el final del relato, cuando Lázaro intenta imponer a la fuerza sus deseos (que Inés aborte) el resultado es su propia muerte a manos de ella.

La relación de Lázaro con los hombres será siempre de enfrentamiento, pues siendo el antagonista del relato sus objetivos serán contrarios a la de la mayoría de los personajes de la historia. Sin embargo a nivel físico, en más de una oportunidad Lázaro será derrotado por los otros personajes masculinos, mostrándolo como un ser envalentonado pero que en la realidad es débil. Finalmente, Lázaro es padre de Lucero, y logrará quitársela a Estrella y tenerla consigo. Sin embargo, Lucero será solamente un fastidio para él. Su necesidad de cuidados, atención y tiempo serán siempre desatendidos por Lázaro. 


\subsection{Kike}

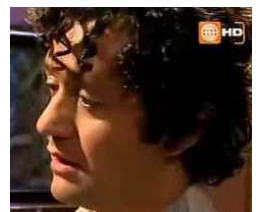

-Si bien la edad de este personaje podría ser similar a la de los otros dos previamente analizados, lo ubicamos en un rango ligeramente menor, entre 25 y 29 años. Es un personaje trigueño, con ligeros rasgos de mulato, pelo ensortijado y una contextura similar a la de Lázaro, aunque con algunos aspectos de mejor capacidad física -derivados del hecho que supuestamente hace deporte constantemente. Su vestuario es informal, y en ocasiones deportivo, llegando en algunos casos ser similar al de Pedro -camisa (colorida) abierta dejando ver un bividí- y en otros abiertamente informal: solo un bividí (como ropa interior) en casa, sobre todo en la época en que se encuentra desempleado. Más allá de su cabello que parece estar algo desordenado, su rostro se muestra cuidado, afeitado y limpio. Utiliza un corto collar de cuero como único accesorio.

La dimensión psicológica nos propone a Kike como un personaje irresponsable y flojo. Por quedarse dormido (se sugiere que es algo que ha pasado varias veces) pierde el trabajo, y a lo largo del relato hace poco por conseguir uno nuevo. Hacia el final es asistente de Pedro en el mercado, pero su capacidad proveedora es limitada y depende de su nueva pareja. El pasado y los objetivos de Kike no son claros en el relato. No se sabe nada de su procedencia, y parece ser un sujeto dedicado a pasarla bien, sin muchas responsabilidades.

La dimensión social para este personaje lo muestra como esposo de Lily en la primera parte del relato. Luego que ella lo expulsa de la casa es cobijado por Pedro, y finalmente inicia una relación con Susana, quien al final del relato no le acepta la propuesta de matrimonio, y continúan juntos aunque sin casarse. En la primera parte Kike es chofer de un microbús, pero es despedido por su irresponsabilidad. Como ya hemos señalado, después de este incidente no tendrá oficio fijo y principalmente aparecerá como desempleado o ayudando a Pedro. El relato no nos muestra su mundo privado, pues rara vez aparece solo, pero sí es abundante en lo que se refiere a sus momentos de ocio: juega fútbol, bebe, ve televisión con amigos, gasta el dinero que su mujer gana y se endeuda.

La dimensión sentimental lo muestra como un personaje sin familia, pero con deseos de tenerla. Al inicio tiene una relación estable y formal, y hacia el final del relato ha construido una nueva relación e intenta formalizarla de la manera más normativa: el 
matrimonio. Es un sujeto que finalmente desea hacer las cosas como los mandatos sociales indican, pero no lo logra por factores externos a él. Es un personaje que es infiel a su pareja, pero a diferencia de otros hombres del relato no es un sujeto que va en busca de esa infidelidad. Resulta por el contrario un instrumento de la sexualidad de Inés, y de sus planes. En relación con otros personajes masculinos, Kike se comporta como un "gallito", pero a las finales se acobarda. Esto no impide que en la parte final del relato luche por lograr justicia para los personajes más débiles. Finalmente, su relación con personajes menores de edad es amical, pero distante. No llega a involucrarse en sus problemas, más allá de lo que los otros personajes le exigen.

\subsection{Próspero ("popó”)}

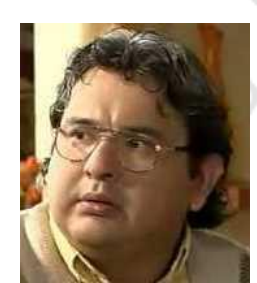

-Este es el personaje de mayor edad de los cinco elegidos, y se ubica en el rango entre los 40 y 45 años. Se puede describir a Próspero como un personaje criollo, de típico mestizaje limeño, de una clase socioeconómica media. A diferencia de los demás personajes masculinos, es un hombre con evidente sobrepeso, de cuerpo fofo, cuyo rostro muestra grandes mofletes y un peinado antiguo. Si bien no tiene ningún tipo de accesorios, usa lentes que remarcan su rostro redondo. Su vestimenta es sobria, y por lo general utiliza camisa y chompa (suéter) que siempre está semiabierta, como si no pudiera cerrarse por completo.

La dimensión psicológica nos hace apreciarlo como un personaje sumiso, que discute poco con los demás personajes, y principalmente con su esposa. No sabemos mucho de su pasado, pero es obvio que se trata de un personaje que ha tenido algún tipo de educación en contabilidad, y que ha trabajado desde joven para proveer a la familia. Sin embargo quien ha sabido administrar el dinero y hacerse de un negocio es su esposa, y no él. Próspero desea reconocimiento, desea que se aprecie su esfuerzo y trabajo, y su objetivo principal es sentirse querido. Estos deseos serán a lo largo del relato los que le cuesten mucho de lo logrado.

En la dimensión social podemos indicar que es un hombre casado con Doralisa, y se encarga de hacer los trámites administrativos y llevar la contabilidad del mercado que ella posee. Conocemos el mundo privado de Próspero y sabemos de sus deseos, tanto por ser reconocido en lo que hace, además de desear relacionarse con otras mujeres. Esos deseos lo harán ser infiel, primero con Olivia (hermana de Doralisa, 
quien quedará embarazada por esa relación extramatrimonial) y luego con Inés, quien lo engañará y hará sentirse querido para apropiarse del mercado. Los pocos momentos de ocio que se muestran de él los utiliza para compartir con sus hijos, viendo televisión en casa.

La dimensión sentimental de Próspero ya ha sido adelantada en el párrafo anterior: en el inicio relación conflictiva con su esposa, quien constantemente le reclama y humilla públicamente; luego una relación sentimental más fuerte con su cuñada Olivia, y finalmente una relación más bien sexual con Inés. Es padre de familia, y a pesar de sus errores serán sus dos hijos quienes lo valoren al final del relato, a pesar que él deba alejarse de ellos y del hogar. Su relación con los otros hombres del relato es servicial, e intenta ser amigo de todos.

\subsection{Armando}

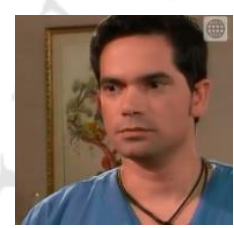

-Este personaje no tiene tanta presencia en el relato como los cuatro anteriores, apareciendo recién en el capítulo 8 y teniendo presencia activa en apenas 20 de los capítulos. Sin embargo su protagonismo toma fuerza en un par de líneas argumentales a partir de la mitad del relato. Su edad debe rondar los 30 años, y es un personaje que viste la mayoría de tiempo con un polo color cian (azul hacia los capítulos finales), que lo reafirma en su profesión: veterinario. Cuando no está utilizando el uniforme se viste con una camisa sport, casaca y jeans. Usa como accesorio una gargantilla de cuero, y en uno de los brazos una muñequera con motivos étnicos selváticos, y una pulsera de cuero. Su rostro se muestra cuidado, afeitado, con cabello corto y sin ninguna marca representativa. Su contextura física es promedio, y étnicamente se le puede ubicar como un criollo costeño blanco. Si bien no se le ve muy musculoso, en enfrentamientos físicos (con Lázaro) sale vencedor.

En la dimensión psicológica se muestra como un hombre serio, responsable, respetuoso, y sobre todo, justo. Cuando Olivia le dice que ha decidido terminar la relación que ambos tienen, él se resiente pero acepta su decisión; y cuando ella propone dejar de trabajar para él, Armando le indica que una cosa no tiene que ver con la otra, y que ella necesita el trabajo y puede quedarse. La honestidad es un valor importante para él y la exige en los demás, pero también exige que no se cuestione la suya. Es un personaje que asume sus responsabilidades, como en el caso donde descubre que Olivia está embarazada, y sospecha que el padre puede ser él, y exige conocer la paternidad para asumirla, si fuera necesario.

En la dimensión social es un profesional, que trabaja y tiene su propio negocio de veterinaria. En buena parte del relato su espacio principal es la 
veterinaria, donde se le ve trabajando, mostrando buen ánimo con los clientes, y preocupación por el bienestar de los animales. Su posición socioeconómica se ve sólida, y se desenvuelve como un hombre con recursos.

En la dimensión sentimental Armando inicia el relato sin compromisos. Es el hermano mayor de Florencia, y se preocupa por la relación sentimental que ella tiene con Aníbal. En esa línea la cuida, la protege, y está dispuesto a defenderla si esa relación no va "como es debido". En los primeros capítulos que tiene presencia, establece una relación sentimental con Olivia, que se desarrolla de forma muy ceremoniosa y respetuosa. Es Olivia quien pide -huyendo del acoso de Prósperopasar la noche con Armando, quien se sorprende por la rapidez del cambio de la relación

Posteriormente Olivia termina la relación, y Armando iniciará una relación con Lily, con quien finalmente se casará, y adoptarán a Yazmín.

\section{Las masculinidades presentes en La Reina de las carretillas}

A partir de la teoría de género y del análisis hecho de los personajes, podemos perfilar algunas representaciones de masculinidad que se dieron en La Reina de las carretillas.

Delinearemos las masculinidades representadas por cada personaje.

"Se supone que la supervivencia del grupo familiar y de la sociedad en su conjunto depende de sus esfuerzos" (del varón) (Fuller, 2012, p. 127)

El caso de Pedro propone una masculinidad que tiene valores reconocidos por la masculinidad patriarcal. Es fuerte, trabajador, responsable, y cuida el honor de los demás. Si bien Estrella no es su familia en buena parte del relato, él se encarga de protegerla, de velar por ella e intenta asegurarse de su bienestar. Fuller nos indica que la paternidad es la hombría perfecta, muestra que ya no se es macho inmaduro, sino hombre (Fuller 1997, p. 168), pero durante el relato Pedro no tendrá hijos ${ }^{3}$, pero se ha casado con Estrella y convertido para todos los efectos en el padre de las dos niñas criadas por ambos (la hija de Estrella y la de Inés). Es decir, tiene los elementos de madurez y equilibrio que, a pesar de no procrear él mismo una descendencia, lo conforma como padre.

Sin embargo, el personaje está lejos de representar el modelo patriarcal. Por un lado, adolece de elementos que lo conviertan en la cabeza de familia: su trabajo no le permite ser proveedor de la familia (a pesar que, como hemos señalado en el acápite anterior, ante necesidades de dinero de pronto aparece con un monto sin explicación de 
cómo lo tiene), no demuestra su virilidad con ninguna mujer ya que no las conquista ni tiene sexo con ellas, aunque se encarga de establecer que no es homosexual ("No tengo novia ni ningún compromiso. Pero por si acaso, tampoco se me moja la canoa ${ }^{4,}$ le dice a Doralisa en el capítulo 4). Sin embargo, a pesar que su fidelidad hacia Estrella es objeto de burlas amistosas ("Pedro es el más monse de aquí. Este nunca le va a sacar la vuelta a Estrellita", indica Kike cuando están en un grupo de hombres en el capítulo 40), su fidelidad también se relaciona a la nobleza, al comportamiento adecuado de un hombre "formado". Igualmente, Pedro no ejerce poder sobre Estrella, ya que su relación es más horizontal y de apoyo y comprensión frente a sus problemas y necesidades

Aun así, esto no se realizará sin crisis y dificultades para él, como explicita en una conversación: "Estoy cansado de ser el bueno. Sólo se hace lo que ella quiere. Tengo que aceptar su voluntad", a lo que Kike le responde "Ese es tu rol, tu eres su gil, tienes que hacer eso. Además justo Estrella te ha escogido a ti porque eres así, monse y mongolón", reafirmando la visión de pares, donde el hombre demasiado bueno es visto como tonto, la masculinidad igualitaria desvalorizada por otros varones.

Al final del relato Estrella es quien adquiere fama y se vuelve exitosa, y Pedro trabajará en la empresa en labores administrativas. Este tipo de relación nos muestra la representación de un modelo igualitario, democrático. Es interesante ver que el principal personaje masculino (aunque no sea el protagonista) encarna esta masculinidad, que es el ideal al que la sociedad está apuntando en el discurso oficial. "Emerge una identidad alejada del machismo. El nuevo hombre, el democrático, es quien atraviesa por diversas crisis de identidad; se debate entre los roles convencionales y los alternos que ahora debe asumir" (Cruz y Ortega, 2007, p. 123)

\section{"Un varón puede ser un padre amoroso, un gran místico o un artista creativo, pero, aun así, todavía tiene que dar pruebas de que es productivo" (Fuller 1997, p.}

130).

A diferencia de Pedro, Lázaro es un hombre casado, que trabaja y tiene una hija. Pero como advierten varios autores ingresar al mundo laboral no significa la condición de adulto. De esta forma Lázaro no es un varón proveedor, no puede sostener a su familia, lo cual lo convierte en un sujeto masculino incompleto. Eso no evita que despliegue su virilidad con distintas mujeres, e incluso tengo otra hija con Inés, de quien durante todo el relato se dice que no puede tener hijos a pesar de todos sus intentos. Sin embargo, a Lázaro poco le importarán sus hijas, no deseará responsabilizarse ni ocuparse de ellas. De otro lado, es un hombre con cierta fortaleza física, pero que utilizará principalmente contra las mujeres, como una forma de reafirmación de su dominio. Lázaro no solo mostrará ese dominio a través de la 
violencia, si no también controlando las acciones de su esposa, como cuando le prohíbe a Estrella ir a la playa, "y menos con ese vestidito" (Cap. 1). Ya hemos indicado en párrafos anteriores que las clases populares urbanas toman con fuerza el modelo tradicional, pero la precariedad material y la dependencia frente a grupos dominantes configuran relaciones de género con exacerbación de dominio masculino (Fuller, 2001, p. 40). Estas son características típicas del hombre machista, que impone sus propias normas a través de la fuerza y el desapego a la responsabilidad. Sin embargo frente a los hombres el personaje muestra cierta debilidad, (resulta vencido en varios enfrentamientos físicos) y su manera de resarcirse demuestra cierta cobardía, lo que va acorde con lo propuesto por Cruz y Ortega: el machista "se fundamenta en las apariencias: la cobardía se esconde detrás de alardes vacíos" (Cruz y Ortega, 2007, p. 136).

"Dile a tu marido que te deje hacer tus cosas, y que trabaje de vez en cuando". (Doralisa a Lily Cap. 4)

Kike comparte algunas características con Lázaro, ya que aquí se representa a un personaje no proveedor, quien tiene un trabaja al inicio, pero luego no consigue trabajo ni hace nada para conseguirlo. La necesidad de que un varón sea proveedor es remarcada por Doralisa en varias oportunidades. Sin embargo el carácter irresponsable de Kike valora su hombría como herramienta para no trabajar "Yo no estoy para cachuelos, negrita" le dice Lily, "Yo soy el hombre de esta casa y debo traer buen billete, no moneditas" (Cap. 6). Kike valora su virilidad y hace gala de ella. E1 excusarse por llegar tarde a una reunión indicando que se había retrasado por haber estado teniendo sexo con su esposa, resulta el motivo por el cual Inés le presta atención y lo considere como una buena posibilidad para quedar embarazada. Cuando van a estar juntos por primera vez, él le dirá "conmigo ya no vas a querer estar con nadie más" (Cap. 6), resaltando su virilidad y potencia sexual. Sin embargo esta virilidad no es suficiente para lograr el estatus de varón hegemónico, pues esta debe estar acompañada de otras características, que están ausentes en él. La virilidad debe ser acompañada por la responsabilidad, de lo contrario es un hombre reproductor, no es un varón logrado. (Fuller 1997, p. 169). Ese varón a medio camino, lo coloca en un nivel que animaliza al sujeto, y Kike representará la idea del macho incontrolable, con un lado que no puede contenerse, como cuando justifica su infidelidad con Inés, diciéndole a Pedro "Se te pone ahí, en bandeja de plata; y uno es varón pues" (Cap. 20). 
Kike intentará por todos los medios mantener el poder, a pesar de su falencia de proveedor. Ese poder le hace sentir que debe determinar lo que su esposa puede o no pude hacer, como cuando llega borracho y encuentra a Lily conversando con Armando en la sala de su casa, e increpa "¿Qué hace un hombre en esta casa con mi mujer cuando yo no estoy?" (Cap 21). Tampoco aceptará que, a pesar de sus falencias, se le realice reclamo alguno, como cuando Lily empieza a sentir que se está demorando demasiado en conseguir un trabajo, lo llama mantenido y le exige que consiga trabajo; su respuesta sigue siendo desde una posición privilegiada, reclamándole que ella no le presta atención (Cap. 20).

Pero no será su incapacidad de ser varón proveedor lo que su esposa no le perdone, si no su infidelidad. Cuando lo expulsa de la casa él pide perdón y le dice que "uno es hombre, con ella fue un revolcón pero a ti te amo; seguro me puso algo en la comida" (Cap. 22), justificándose en lo que la construcción de género denomina el lado indomable de los hombres.

De todos los personajes masculinos presentados en este relato, Kike es el único que explícitamente indica hacer deporte (aunque nunca se le vea hacerlo). Este aspecto según Fuller, es una de las características del macho. "Un varón debe incentivar la fortaleza a través del deporte y el cuidado de la apariencia" (Fuller, 2001, p. 68).

Pero a diferencia de Lázaro, Kike sí se preocupa por su relación, entiende el dolor que le ha causado a su pareja por serle infiel, desea formar una familia verdadera, e intenta lograrlo hacia los últimos capítulos cuando le propone matrimonio a su nueva pareja, Susana. Desafortunadamente para él, su imagen anterior, y los propios deseos y aspiraciones de Susana juegan en su contra, y ella rechaza el matrimonio pero no la relación entre ambos: "No pienses, que para eso no sirves. Tú sirves para foguearme, para calentarme, para darme sensaciones" establece ella (Cap. 40). De esta manera, planteamos que si bien Kike corresponde a muchas características del hombre machista, la ausencia de su violencia, su nivel de preocupación por su pareja, su deseo de establecerse, y el grado de poder que finalmente otorga a su nueva pareja, genera un cariz diferente, la del hombre viril, ese estadio que parece eternamente en tránsito entre el joven que se está haciendo hombre, y el hombre ya plenamente formado. Encontramos así un tipo de macho ligeramente diferente, una variación del machismo, donde la virilidad, la conquista femenina, la presencia física son elementos que se 
manejan de manera importante, sobre todo en el ámbito público frente a los pares. Pero en el ámbito privado se desarrolla de forma distinta, ya que ejerce un poder menos potente frente a la familia, no llega a la violencia, e intenta que sus acciones en la esfera pública no tiñan o desestabilicen el ámbito privado. Una figura un poco más igualitaria con la pareja donde también subyace un deseo de acercarse más al ideal del varón patriarcal, pero manteniendo algunos de los privilegios del machista, como las posibilidades de la conquista sexual de las mujeres. La virilidad, tanto dentro del hogar como fuera de él, será una de sus características principales, por lo que le llamamos el hombre viril.

\section{"Todo príncipe se convierte en chancho, o peor, en el hombre invisible: nunca está cuando lo necesitas, (...) o está en las nubes". (Doralisa,} Cap. 2)

Con esta frase se presenta a Próspero en el relato, a través de lo que su esposa dice sobre él. Desde el primer momento, aún ausente en la pantalla, Próspero pone en evidencia los mandatos de la masculinidad y la crisis de ésta en la sociedad cambiante. El tiene características típicas de un hombre para representar un modelo patriarcal, pues la jefatura del hogar es fuente de masculinidad, al igual que la paternidad (Cruz y Ortega, 2007, p. 137-138). Pero a pesar de ser padre de dos hijos, casado, administrador de un negocio, representa al hombre emasculado. El poder que posee su esposa Doralisa en la relación familiar, y en los negocios, minan las posibilidades de Próspero para ejercer una masculinidad dominante. El intentará llevar las riendas del hogar y de los negocios, pero será ella quien siempre tenga el control y la decisión final sobre todos los asuntos, tanto domésticos como públicos. "Un varón que fracasa en el intento que su esposa reconozca su autoridad última sobre ella y sobre la familia, pierde su condición masculina" (Fuller 1997, p. 160). Y esta condición perdida es vista por los diferentes personajes del relato. Cuando le pide a Pedro que pinte los locales del mercado, este le responde "No sé don Próspero, no quiero tener problemas con su señora" (Cap. 14). Al interior del hogar, son sus hijos -en especial Aníbal- quien recuerda en más de una ocasión quién tiene el poder en el hogar. "¿Por qué estás asado? Seguro que mi vieja ya te dio una catana" (Cap. 8). Próspero pregunta "¿Cuándo te vas a poner a estudiar? Tu madre dice..." a lo que Aníbal replica "¡Tu madre, tu madre! Solo sabes repetir lo que la vieja dice. Con razón dicen que eres su Natacho" (Cap. 3)

La situación de Próspero es minada públicamente, pues en varios capítulos Doralisa le reclama en el mercado por no haber hecho las cosas como deben hacerse o como ella desea. No sirves para nada, nunca haces bien las cosas, ¿por qué me haces esto? son las frases que dice a voz en cuello frente a todos los demás. De esta forma se le muestra como una versión precaria de ser varón, lo que lo coloca en una posición subordinada frente a los demás (Fuller, 2012, p. 118). Sin embargo él tratará a lo largo 
del relato de sacudirse de esta situación, y de enfrentar a Doralisa. Luego de una humillación pública, Próspero exclama ante Estrella "Como siempre, ella es la dueña de todo" (Cap. 6), logrando la solidaridad de Estrella. Más adelante en el relato, le dice a su esposa "Para ti eres la mejor madre, la mejor empresaria, la mejor patrona. Y seguro también crees que eres la mejor esposa" (Cap. 7) lo cual Doralisa resiente, pero no desarrolla ningún cambio. En otro enfrentamiento con Doralisa le dice "Soy tu marido. No soy un esclavo, y mucho menos un empleado tuyo" (Cap. 13).

Estas situaciones nos muestran a un personaje que, si bien se encuentra en una posición de masculinidad disminuida, trata de lograr una relación menos asimétrica, y terminará intentando recuperar los privilegios de la masculinidad dominante. En sus textos, Fuller enfatiza el valor de la sexualidad activa para la masculinidad, y advierte que si la mujer la domestica se puede emascular al varón (Fuller, 2001, p. 124). "El eje natural de la masculinidad es la virilidad, definida como el aspecto no domesticable de la masculinidad" (Fuller, 2012, p. 123). Esta figura es la que desarrollará Próspero en la parte media del relato. Obsesionado con su cuñada, tratará de establecer con ella una relación, la cual será rechazada en un principio por Olivia, recordándole que es su cuñado. "Pero también soy un hombre" le responde Próspero, forzándola a besarlo. (Cap. 10). Finalmente logra establecer una relación con ella, pero esta finaliza cuando es amenazada por su hijo Rommel, quien descubre el romance. En capítulos posteriores establece un romance con Inés, quien lo manipula elogiando su lado viril y masculino. Finalmente, al conseguir Inés sus propósitos y descartarlo, Próspero queda expuesto, rechazado por su familia, humillado frente a todos, culpable de la desgracia de su familia y de la gente del mercado. Sin hogar, sin trabajo, sin dinero, sin amigos ni familia, Próspero queda en el escalón más bajo de la masculinidad, un sujeto disminuido y despreciado, dominado por una mujer que lo ha manipulado y se ha aprovechado de su ingenuidad. En su última aparición, solamente su hijo Rommel le otorgará algún valor. Al irse a despedir pues ha conseguido un trabajo en el norte del Perú, dice a su familia que ahora podrán ser felices, a lo que Rommel responde "No papá, nos vas a faltar tú" (Cap. 41). El abrazo final con sus hijos, mientras su esposa le da la espalda, propone un personaje debilitado, pero que a pesar de sus errores es reconocido como un padre cariñoso, que ha sembrado en sus hijos-hombres algún valor para continuar en la vida.

\footnotetext{
${ }^{5}$ En referencia a la telenovela de inicios de los años 70 "Natacha", donde el personaje principal era una trabajadora del hogar.
} 
"Él es el tipo de hombre que no se va a quedar soltero. Está buscando una mujer para tener niños, familia, asentarse" (Doralisa sobre Armando, Cap. 13)

Armando es la representación del varón con la cual formar un hogar, un hombre responsable, cariñoso, proveedor. Es el personaje al que finalmente se puede acudir en una crisis, que va a actuar de manera adecuada y pensando en el beneficio de los demás antes que en el suyo propio. Si bien no ha finalizado de formarse como el varón completo, con una familia, hijos y las responsabilidades de los mandatos de género, demuestra que está capacitado para hacerlo en todos los niveles. Se preocupa por la situación de su familia sanguínea (su hermana) y aún dándole libertad para que decida, está siempre pendiente de lo que pueda ocurrirle. Es un hombre responsable y que no rehúye la paternidad, como ya hemos señalado al indicar que si el futuro bebé de Olivia fuera suyo, él se haría cargo. Obviamente su posición económica y profesional lo ubica en una posición confiable para ser proveedor de una familia.

Aunque no tiene hijos, pues aún no tiene una familia constituida, se preocupa por Yazmín, el único personaje infantil del relato, y en el final la adoptará junto con Lily, y se convertirá de inmediato en un padre de familia generoso, cariñoso, adorado por su hija.

Otra característica del varón proveedor es la honorabilidad, la de su familia y la propia. Cuando Olivia confirma que él no es el padre, pero se niega a revelar el nombre de quien la embarazó, Armando insiste en saberlo para obligarlo a hacerse responsable de la paternidad, y la apoye. Esto no evita que él de todas maneras ayude a Olivia con los problemas de salud que su recién nacido tiene, se solidarice con ella e intenté lograr una solución. Igualmente, el punto culminante de su relación con Lily será su matrimonio, y la constitución formal de un hogar.

Pero la defensa del honor también es propia, como hace evidente cuando es acusado de ser el padre del recién nacido, y hasta Lily duda de su palabra. En este caso exige hacerse una prueba de ADN, pero le advierte a su actual pareja: "Yo no voy a vivir con una persona que no cree en mí, que no me apoya y no confía en mí. Pero a pesar de todo eso, yo te quiero" (Cap. 29).

Finalmente, si bien Armando es el personaje más cercano al modelo de la masculinidad patriarcal, muestra también rasgos de una masculinidad más moderna y 
democrática. Apoya a su esposa para que surja con su propio negocio, se vislumbra que aceptará una división del trabajo en el hogar y de las decisiones familiares.

\section{Discusión}

La reina de las carretillas es, como cualquier ficción televisiva, un instrumento de representación, donde puede verse reflejado un imaginario de sociedad. Frente a la crisis de la masculinidad patriarcal, surgen relatos en que muestran feminidades y masculinidades diferentes, siendo esta ficción una de ellas.

Frente al relato protagonizado por mujeres fuertes, empoderadas, independientes, La reina de las carretillas presenta personajes masculinos que representan diferentes tipos de masculinidades que existen en la sociedad peruana (igualitario, machista, viril, emasculada), alejadas en buena parte de la masculinidad patriarcal.

Este alejamiento se debe por un lado, a situación socioeconómica de los personajes, pues la mayoría de ellos tienen dificultades para poder mantener a la familia, que es una de las características principales del macho proveedor propuesto por la masculinidad patriarcal. Sus reducidos recursos les dificultan lograr el ideal masculino, y por ello se ubican en otros tipos de masculinidades.

Pedro representa un tipo de masculinidad que responde al discurso oficial: un hombre igualitario. Frente a la fuerza de la protagonista, él no puede ni debe imponerse a ella, y por el contrario debe ser un sujeto que recorra, junto con ella, el devenir del relato. La propuesta actual del relato va de esta manera con lo políticamente correcto, y ubica al varón coprotagonista como un ser que lucha entre cumplir con los mandatos patriarcales (proveedor, protector de la familia) y los de una nueva sociedad que otorga espacio y agencia a las mujeres. De esta manera su representación es positiva, y se convierte en un modelo a seguir. Es importante resaltar que a pesar de ser un relato de protagonistas femeninas, este personaje es el más importante de todos los personajes masculinos, y por ello resulta sintomática la propuesta del modelo principal que muestra una forma de comportamiento positivo. Este modelo se aleja de las galanes del melodrama clásico, que finalizaban realizando la felicidad de la protagonista femenina convirtiéndola en su esposa y ama del hogar provisto por él. 
Lázaro, como antagonista, es la representación a rechazar: la del machista. Cualquier intento por convertirse en un varón patriarcal será anulado por su propia condición y por su temperamento. Su falta de posibilidad de ser sujeto proveedor, su carácter violento, su dominio sobre las mujeres como única forma de prestigio, y sobre todo su desapego y falta de responsabilidad frente a su descendencia, hacen que sea una representación que va en contra de los valores actuales. Su representación subrayará siempre un elemento a ser rechazado, a no ser aceptado por la sociedad, y por ello el personaje será castigado con la muerte al final del relato. Esto se relaciona con los relatos melodramáticos clásicos, donde los villanos reciben castigo, respondiendo a la moral de los tiempos. Pero Lázaro no puede recibir el castigo clásico de los relatos patriarcales, el cual es la ruina económica o el descrédito social, ya que no posee ninguno de esos atributos. Su castigo moral finaliza con una muerte deshonrosa -en la calle- a manos de la mujer que trató de someter.

Kike muestra una faceta diferente del machismo, que se aleja de la violencia y se ubica en el ámbito de no ser productivo, y con características de tránsito que no le permitirá avanzar hacia la "hombría completa". Sin eliminar los elementos negativos de Kike y su machismo, su personaje presenta características de tránsito, y en el relato ese será su estado eterno. Su relación final con una mujer que no permite que él tenga la decisión final, mina su carácter machista y lo ubica en lo que proponemos como un modelo de hombre viril, que también finaliza debilitado frente a una mujer que decide el futuro de ambos, y él deberá ceder terreno en el poder y toma de decisiones de la pareja, aunque manteniendo la virilidad como el elemento central de la relación.

Próspero representa al varón emasculado pero en constante deseo de sacudirse de esa situación, y acercarse así a un modelo patriarcal más clásico. Dominado por el carácter femenino más avasallador del relato (Doralisa), sus intentos por sacudirse de la emasculación simplemente lo hundirán más y lo colocarán en una situación de alta fragilidad que lo harán terminar en una situación aún más desventajosa que la inicial. La ruptura de las características patriarcales de Próspero lo hacen perder lo más sagrado en la sociedad patriarcal: la familia, el hogar. Dentro del discurso oficial, Próspero nos presenta una doble representación. Por un lado lo que puede suceder si la igualdad se desbalancea en una asimetría hacia la mujer, y por otro, lo que puede suceder si el varón empieza a priorizar su virilidad antes que sus mandatos y responsabilidades con la familia. 
Finalmente el caso de Armando es el más cercano a la masculinidad hegemónica, pues cumple con varias de las características que ésta exige. Resulta interesante su ingreso tardío al relato y su presencia casi tangencial con las historias principales (hasta que se relaciona con Lily en la segunda parte del relato), siendo un personaje bastante secundario. Si bien Armando puede ser el representante del galán clásico, igual es teñido con cierta sensibilidad y características más cercanas al discurso políticamente correcto.

De esta manea podríamos vislumbrar una propuesta de relato donde, frente a la crisis del modelo patriarcal, los discursos de los medios masivos presentan imaginarios de una sociedad mejor, pero sin dejar de responder a los mandatos hegemónicos que subsisten. Los personajes se alejarán del modelo patriarcal y los que intenten retornar a él fracasarán, ya sea muriendo, no logrando dominar a sus parejas, o siendo desterrados del relato. Solo aquellos que se alejan del modelo patriarcal y proponen una relación más igualitaria tienen un final realmente feliz.

\section{Referencias}

Abric, J. C. (2011) Prácticas sociales y representaciones. México: D.F. Ediciones Coyoacán. Tercera edición.

Adrianzén, E. (2001) Telenovelas. Cómo son, cómo se escriben. Lima: Fondo Editorial PUCP.

Arias, R., \& Cano, A. M., \& Cuadros, L., \& Quiroz, M.T. (1993) Sobre la Telenovela.

Historia y condiciones de producción de la telenovela peruana. Análisis textual de tres

telenovelas. Lima: Nexus, Colección Interfacultades. Universidad de Lima.

Bourdieu, P. (1997) Sobre la televisión. Barcelona: Editorial Anagrama.

Bourdieu, P. (2000) La dominación masculina. Barcelona: Editorial Anagrama.

Brooks, P. (1995) The Melodramatic Imagination. Balzac, Henry James, Melodrama and

the mode of excess. New Haven: Yale University Press. 
Callirgos, J. C. (1996) Soldados desconocidos: notas sobre el Machismo latinoamericano.

Márgenes. Encuentro y Debate $N^{\circ} 15$. Lima: SUR.

Cassano, G. (2014) Mirando la Telenovela desde el Género. Natacha: De la Domesticidad a

la Agencia. Acao Midiática (8). Curitiba: UFP.

http://ojs.c3sl.ufpr.br/ojs2/index.php/acaomidiatica/issue/view/1844 Consulta: 10 de Marzo

2015

Castells, M. (1998) La era de la información. Economía, sociedad y cultura. Madrid:

Alianza editorial.

Cruz, B., \& Ortega, M., (2007) Masculinidad en crisis. En M. L. Jiménez \& Tena, O.

(coord) Reflexiones Sobre masculinidades y empleo. Cuernavaca: UNAM.

Connel, R. (1995) La organización social de la masculinidad.

http://www.hombressinviolencia.org/docs/ORGANIZACION_MASCULINIDAD.pdf

Consulta: 10 de Marzo 2015

Feasey, R. (2008) Masculinity and popular television. Edimburgo: Edinburgh University

Press.

Field, S. (2002) El manual del guionista: ejercicios e instrucciones para escribir un buen guión paso a paso. Madrid: Plot Ediciones.

Fuenzalida, V. (1996) La apropiación educativa de la telenovela. Diálogos de la Comunicación (44), 91-104. Lima.

Fuller, N. (2012) Repensando el machismo Latinoamericano. Masculinities and social 
change (1). 114-133.

Fuller, N. (2001) Masculinidades, cambios y permanencias. Lima: Fondo Editorial PUCP.

Fuller, N. (1997) Identidades Masculinas. Lima: Fondo Editorial PUCP.

Galán Fajardo, E. (2006) Personajes, estereotipos y representaciones sociales. Una propuesta de estudio y análisis de la ficción televisiva. Eco-pos, 9 (1), Enero-Julio. Rio de Janeiro: UFRJ.

Gutmann, M. (1999) El machismo. En M.C. Gutmann Ser hombre de verdad en la ciudad de México: Ni macho, ni mandilón. México: Colegio de México y Editorial Paidós.

Hall, S. (2010) Sin garantías: trayectorias y problemáticas en estudios culturales. Popayán: Envión Editores. IEP, Instituto Pensar, Universidad Andina Simón Bolívar sede Ecuador.

Kimmel, M. S. (1997) Homofobia, temor, vergüenza y silencio en la identidad masculina En Valdés, T. \& Olavarría, J. (Ed). Masculinidad/es: poder y crisis, (pp. 4962) Cap. 3, Santiago: ISIS-FLACSO: Ediciones de las Mujeres (24).

Kogan, L. (2010) El deseo del cuerpo. Mujeres y hombres en Lima. Lima: Fondo editorial del Congreso del Perú.

Lamas, M. (comp.) (1996) El género: la construcción cultural de la diferencia sexual. México: Coordinación de Humanidades, Programa Universitario de Estudios de Género. UNAM. Lamas, M. (1995) Cuerpo e identidad. Pg. 61 - 81. EN Género e identidad: ensayos sobre lo femenino y lo masculino. Tercer Mundo. Bogotá.

Lozoya, J. A. (1999) ¿Qué es eso de la identidad masculina?

http://www.edualter.org/material/masculinitat03/identidad.htm Consulta: 26 de Marzo 2015

Mac Kinnon, K. (2003) Representing men. Maleness and masculinity in the media. Londres: Hodder Headline Group. 
OBITEL. (2013) Anuario 2013, Memoria social y ficción televisiva. Porto Alegre: Editora

Sulina.

Olavarría, J., \& Parrini, R., (2000) Masculinidad/es. Identidad, sexualidad y familia. Red

de masculinidad- Chile, FLACSO- Chile, Universidad Academia de Humanismo Cristiano.

Paulson, S. (2013) Masculinidades en movimiento: transformación territorial y sistemas de género. Buenos Aires: Teseo.

Pescatello, A. (1977) Hembra y macho en Latinoamérica: ensayos. México: Editorial Diana.

Reeser, T. (2010) Masculinities in theory, an introduction. United Kingdom: WileyBlackwell.

Valdés, T., \& Olavarría, J., (Ed.) (1998) Masculinidades y equidad de género en América

Latina. FLACSO-Chile. Santiago. 


\begin{tabular}{|c|c|}
\hline Dimensión & PEDRO \\
\hline Física & $\begin{array}{l}30 \text { a } 35 \text { años } \\
\text { Fornido (pectorales) } \\
\text { Arreglado ("buena presencia") } \\
\text { Barba a medio crecer, cuidada. } \\
\text { Jeans y zapatos cómodos, camisas de cuadros abiertas y debajo camiseta sin mangas } \\
\text { ("bividí") } \\
\text { Gargantilla de cuero delgada. } \\
\text { En imaginario peruano es "blanco"6. }\end{array}$ \\
\hline Psicológica & $\begin{array}{l}\text { Sensible. } \\
\text { Calmado, aunque puede exaltarse ante injusticia. } \\
\text { Pasado: preso por asalto, libre por buena conducta. } \\
\text { Oficio: arreglar aparatos eléctricos. } \\
\text { Desea salir adelante sin que se le juzgue por su pasado y conquistar a Estrella, } \\
\text { convirtiéndose en su defensor. }\end{array}$ \\
\hline Social & $\begin{array}{l}\text { Soltero, solo interesado en Estrella. } \\
\text { Clase socioeconómica de recursos reducidos. } \\
\text { Repara equipos eléctricos en un puesto del mercado. } \\
\text { Ocio: alguna fiesta o celebración del mercado. } \\
\text { Hermano menor, involucrado en asalto del cual Pedro se inculpó. }\end{array}$ \\
\hline Sentimental & $\begin{array}{l}\text { En soledad muestra lado sensible, llora. } \\
\text { Actitud de responsabilidad por más débiles (hermano, Estrella) y sacrificio le confieren } \\
\text { dimensión heroica. } \\
\text { Dimensión de adulto protector con Yazmín, (única niña en el relato). } \\
\text { Cuida a los más desvalidos, los defenderá aún con su propio sacrificio. } \\
\text { Única relación sentimental con Estrella. } \\
\text { Relación con personajes masculinos: variable con Kike (en primeros capítulos } \\
\text { enfrentados; posteriormente amical, y de cierta complicidad). } \\
\text { Con Lázaro constante enfrentamiento. } \\
\text { En enfrentamientos físicos con otros varones saldrá vencedor. }\end{array}$ \\
\hline
\end{tabular}

${ }^{6} \mathrm{El}$ actor que lo interpreta es hijo de un renombrado director de cine peruano, y una conocida guionista, provenientes de familias acomodadas. 


\begin{tabular}{|c|c|}
\hline Dimensión & LÁZARO \\
\hline Física & $\begin{array}{l}30 \text { a } 35 \text { años. } \\
\text { Al inicio del relato vestimenta de pescador (pantalón remangado, camiseta). En } \\
\text { Lima pantalón y casaca. } \\
\text { Bien peinado y afeitado, no muestra accesorios. } \\
\text { Contextura "promedio". } \\
\text { Étnicamente se puede ubicar como un criollo costeño peruano7. }\end{array}$ \\
\hline Psic & $\begin{array}{l}\text { Se infiere pasado de familia de pescadores. } \\
\text { Violento, rencoroso, disconforme. } \\
\text { Abusivo con los débiles. } \\
\text { Frente a personajes con mayor poder resulta cobarde. } \\
\text { Irresponsable. } \\
\text { Su objetivo central será recuperar a Estrella, que regrese al hogar. }\end{array}$ \\
\hline & $\begin{array}{l}\text { Casado con Estrella. } \\
\text { Infiel en varias ocasiones. } \\
\text { Pescador, pero no logra mantener a su familia. } \\
\text { Clase socioeconómica de recursos muy reducidos. } \\
\text { En Lima no tiene oficio conocido. } \\
\text { Momentos de ocio: fiestas, otras mujeres, dedicado a la bebida. }\end{array}$ \\
\hline Sentimental & $\begin{array}{l}\text { Inicia el relato casado con Estrella. Luego separado, con ella exigiéndole el } \\
\text { divorcio. } \\
\text { Padre de Lucero, quien será un fastidio para él. Desatenderá necesidades, } \\
\text { cuidados y atención de su hija. } \\
\text { Establece relación -más sexual que sentimental- con Inés, convirtiéndose en su } \\
\text { relación más estable durante el relato. } \\
\text { Relación altamente conflictiva: Inés es un personaje poderoso, que no permite } \\
\text { que Lázaro la deje ni tome decisiones. } \\
\text { Al final del relato, intenta imponer a la fuerza sus deseos, lo que precipita su } \\
\text { propia muerte a manos de Inés. } \\
\text { Relación con personajes masculinos: constante enfrentamiento. } \\
\text { A nivel físico, derrotado por los otros personajes masculinos. }\end{array}$ \\
\hline
\end{tabular}

${ }^{7}$ Los peruanos lo llamarían "blancón" por tener un color de piel más claro que el promedio nacional 


\begin{tabular}{|c|c|}
\hline Dimensión & KIKE \\
\hline Física & $\begin{array}{l}25 \text { a } 29 \text { años. } \\
\text { Trigueño, ligeros rasgos de mulato, pelo ensortijado y algo desordenado. } \\
\text { Rostro cuidado, afeitado y limpio. } \\
\text { Contextura promedio, capacidad física porque hace deporte. } \\
\text { Vestuario informal, camisa colorida abierta, a veces solo ropa interior. } \\
\text { Corto collar de cuero como accesorio. }\end{array}$ \\
\hline Psicológica & $\begin{array}{l}\text { Irresponsable y flojo. } \\
\text { Pierde el trabajo por quedarse dormido. } \\
\text { Pasado y objetivos poco claros en el relato. } \\
\text { Dedicado a pasarla bien, sin responsabilidades. }\end{array}$ \\
\hline & $\begin{array}{l}\text { Esposo de Lily al inicio del relato. Infidelidad rompe matrimonio. } \\
\text { Capacidad proveedora limitada. } \\
\text { Al final: relación con Susana, donde ella decide no casarse. } \\
\text { Ocio: juega fútbol, bebe, ve televisión, gasta dinero de su mujer. }\end{array}$ \\
\hline Sentimental & $\begin{array}{l}\text { Sin familia, pero con deseos de tenerla. } \\
\text { Inicia el relato casado, y al final intenta formalizar nueva relación con } \\
\text { matrimonio. } \\
\text { Desea cumplir los mandatos sociales. } \\
\text { Relación con personajes masculinos: amical, se comporta como "gallito", pero } \\
\text { se acobarda. } \\
\text { Enfrenta a Lázaro para lograr justicia. } \\
\text { Relación con menores de edad amical, pero distante. }\end{array}$ \\
\hline
\end{tabular}

\begin{tabular}{|l|l|}
\hline Dimensión & PRÓSPERO (Popó) \\
\hline \multirow{2}{*}{ Física } & $\begin{array}{l}40 \text { a } 45 \text { años. } \\
\text { Criollo, mestizo limeño. } \\
\text { Sobrepeso, cuerpo fofo, grandes mofletes, peinado antiguo. } \\
\text { Vestimenta sobria, camisa y chompa (suéter) semiabierta, como si no pudiera } \\
\text { cerrarse por completo. } \\
\text { Sin accesorios, usa lentes que remarcan su rostro redondo. }\end{array}$ \\
\hline Psicológica & $\begin{array}{l}\text { Sumiso. } \\
\text { Ha tenido educación en contabilidad, ha trabajado para proveer a la familia. } \\
\text { Desea reconocimiento, que se aprecie su esfuerzo y trabajo. }\end{array}$ \\
\hline
\end{tabular}




\begin{tabular}{|l|l|}
\hline \multirow{5}{*}{ Social } & Objetivo principal: sentirse querido. \\
& $\begin{array}{l}\text { Casado con Doralisa. } \\
\text { Encargado de trámites administrativos y contables del mercado. } \\
\text { Clase socioeconómica media. } \\
\text { Deseos de relacionarse con mujeres. } \\
\text { Será infiel, primero con su cuñada y luego con Inés. } \\
\text { Ocio: con sus hijos, viendo televisión en casa. }\end{array}$ \\
\hline Sentimental & $\begin{array}{l}\text { En el inicio relación conflictiva con su esposa. } \\
\text { Luego relación con su cuñada (a la que embaraza) } \\
\text { Fadre de dos hijos, quienes lo valorarán al final del relato. } \\
\text { Relación con personajes masculinos: servicial, intenta ser amigo de todos. }\end{array}$ \\
\hline
\end{tabular}

\begin{tabular}{|l|l|}
\hline Dimensión & ARMANDO (Dr. Armando Dávila) \\
\hline Física & $\begin{array}{l}\text { Alrededor de } 30 \text { años } \\
\text { Arreglado, afeitado, cabello corto } \\
\text { Polo cian (uniforme médico), casaca sport, camisa y jeans } \\
\text { Gargantilla de cuero y muñequeras con motivos étnicos. } \\
\text { En imaginario peruano es "blanco" }\end{array}$ \\
\hline Psicológica & $\begin{array}{l}\text { Preocupado por estudios de los demás. } \\
\text { Su objetivo central es tener una pareja. } \\
\text { Expresivo y centrado } \\
\text { Cuando ve a Olivia embarazada y cree ser el padre, no rehúye responsabilidad. } \\
\text { Y quiere que padre se haga responsable. }\end{array}$ \\
\hline Social & $\begin{array}{l}\text { Veterinario. Tiene su propia clínica. } \\
\text { Siempre se le ve trabajando. } \\
\text { Clase socioeconómica con ciertos recursos. }\end{array}$ \\
\hline Sentimental & $\begin{array}{l}\text { Preocupado por los demás } \\
\text { Preocupado por su hermana y su posible relación con Aníbal } \\
\text { Se relaciona con Olivia. Ella termina con él. } \\
\text { Se vuelve pareja de Lily, apoyándola, y se casa con ella. } \\
\text { Toma iniciativas. } \\
\text { Al final, adoptan a Yazmín. }\end{array}$ \\
\hline
\end{tabular}

